\title{
PANDANGAN HUKUM ISLAM MENGENAI YURISPRUDENSI \\ TENTANG DELIK ZINA DALAM PERKEMBANGAN \\ HUKUM PIDANA NASIONAL
}

\author{
(A View from Islamic Law of Jurisprudency About Adultery \\ In National Criminal Law Development)
}

Zulfiqar Bhisma Putra Rozi**

Fakultas Hukum Universitas Gresik

Jl. Arif Rahman Hakim No 2B, Sidokumpul, Gresik

E-mail: zulfiqar.putra007@gmail.com

\begin{abstract}
Abstrak
Latar Belakang dari Penelitian ini adalah adanya kelemahan terkait pengaturan atas Tindak Pidana zina sebagaimana yang diatur dalam pasal 284 KUHP yang mana pada pasal tersebut pemidanaannya terbatas pada ruang lingkup perkawinan dan Tidak dapat dipidana bila kedua pelakunya masing-masing masih sama-sama tidak terikat perkawinan. Hal ini mengacu kepada konsep rumusan KUHP yang merupakan adopsi dari Wetboek van Straftrecht Belanda yang menganggap persetubuhan yang dilakukan oleh kedua pelaku yang masing-masing sama-sama tidak sedang terikat perkawinan tidak dianggap sebagai delik zina karena berasumsi tidak adanya korban yang dirugikan. Sementara menurut hukum islam persetubuhan kategori apapun tetap dianggap sebagai perzinaan dan dapat dikenakan hukuman. Untuk dapat mengakomodir kelemahan dalam rumusan pasal 284 KUHP tersebut, dengan berdasarkan pada UU Kekuasaan Kehakiman maka Hakim diberi kewenangan untuk menggali dari nilai-nilai yang berlaku dalam masyarakat agar dapat memutuskan perkara. Selanjutnya putusan hakim tersebut menjadi Yurisprudensi bagi hakim selanjutnya untuk kasus yang serupa. Penelitian ini dilakukan dengan menggunakan metode penelitian yuridis normatif dimana penulis melakukan pengkajian dari studi peraturan perundang-undangan serta putusan-putuan pengadilan yang berkaitan dengan tema penelitian sebagai kajian terhadap pembaharuan hukum pidana khususnya pada rumusan delik zina dalam pasal 284 KUHP.
\end{abstract}

Kata kunci:

Yurisprudensi, Pasal 284, KUHP, Perzinaan, Hukum Pidana Nasional, Hukum Islam

\begin{abstract}
The background of this research is the weaknesses related to the regulation of adultery as stipulated in article 284 of the Criminal Code which in that article the punishment is limited to the scope of marriage and cannot be convicted if the two perpetrators are still each not bound by marriage. This refers to the concept of the Criminal Code formulation which is the adoption of Wetboek van Straftrecht of the Netherlands which considers intercourse committed by both actors who are both not currently bound by marriage is not considered as an adultery offense because it assumes there are no
\end{abstract}


injured victims. While according to Islamic law intercourse, any category is still considered adultery and may be subject to punishment. To be able to accommodate the weaknesses in the formulation of article 284 of the Criminal Code, based on the Judicial Power Act, the Judge is given the authority to explore the values that apply in the community in order to decide on a case. Furthermore, the judge's decision becomes Jurisprudence for the next judge in a similar case. This research was conducted using the normative juridical research method in which the writer conducted a study of the study of legislation and court rulings relating to the research theme as a study of criminal law reform, especially in the formulation of zina adultery in article 284 of the Criminal Code.

Keywords:

Jurisprudence, Article 284, Penal Code, Adultery, National Criminal Law, Islamic Law

\section{PENDAHULUAN}

Sesuai dengan Undang-Undang Dasar Negara Republik Indonesia Tahun 1945, selaku Undang-Undang tertinggi di Negara, Indonesia adalah negara hukum yang menjalankan kehidupan dengan berlandaskan pada prinsip kedaulatan $\quad$ Rakyat. ${ }^{1} \quad$ Pemerintah menegaskan agar seluruh elemen masyarakat mematuhi segala hukum yang telah diberlakukan. Salah satunya adalah Hukum Pidana dengan KUHP sebagai sumber hukum materiilnya dan KUHAP sebagai sumber hukum formilnya. Hukum Pidana adalah merupakan salah satu hukum publik yang diciptakan oleh Pemerintah yang berwenang sebagai salah satu instrumen untuk mengatur kehidupan masyarakat.

Dalam KUHP terdapat beberapa ketentuan mengenai kejahatan terhadap kesusilaan yang diatur dalam Bab XIV Buku II KUHP, salah satunya ialah

\footnotetext{
${ }^{1}$ Lihat Pasal 1 ayat (2) dan (3) Undang-Undang Dasar Negara Republik Indonesia Tahun 1945
}

delik tentang Zina. Perzinaan sebagaimana yang telah dirumuskan dalam Pasal 284 KUHP, adalah termasuk dalam kejahatan terhadap kesusilaan, yaitu perbuatan persetubuhan yang dilakukan oleh lakilaki/perempuan dengan lawan jenis yang bukan merupakan pasangan kawinnya. Dari rumusan pasal 284 KUHP $^{2}$ tersebut, dapat ditafsirkan bahwa perzinaan adalah persetubuhan yang dilakukan oleh laki-laki dengan seorang perempuan yang bukan istrinya, atau persetubuhan antara seorang perempuan dengan seorang laki-laki yang bukan suaminya. Dari rumusan tersebut menurut Adami Chazawi dalam bukunya berpendapat bahwa terdapat 3 unsur esensial yang bisa ditemukan dalam unsur-unsur perzinaan, unsur-unsur esensial itu antara lain melakukan persetubuhan dengan perempuan atau laki-laki bukan suami atau bukan istrinya, bagi dirinya berlaku pasal $27 \mathrm{BW}$, dan dirinya

2 Lihat Pasal 284 Kitab Undang-Undang Hukum Pidana 
sedang dalam ikatan perkawinan. ${ }^{3}$ Dapat ditemukan kelemahan dalam rumusan pasal 284 KUHP, yakni delik zina hanya bisa dijatuhkan pada seorang suami/istri yang melakukan persetubuhan dengan lawan jenis yang bukan pasangan kawinnya. Delik zina tidak bisa dijatuhkan pada perbuatan persetubuhan yang dilakukan antara seorang laki-laki/perempuan dengan lawan jenis yang keduanya masingmasing sama-sama tidak sedang terikat perkawinan.

Karena terdapat kelemahan dalam rumusan pasal 284 KUHP, maka hakim dapat melakukan semacam penemuan hukum dengan menggali dari nilai-nilai yang berlaku dalam masyarakat agar dapat memutus perkara pengadilan bila terjadi persetubuhan antara lakilaki/perempuan dengan lawan jenis yang keduanya masih sama-sama tidak sedang terikat perkawinan sehingga dapat mengakomodir kelemahan yang ada. Untuk selanjutnya putusan hakim tersebut dapat diikuti oleh hakimhakim selanjutnya bilamana menemukan perkara yang sama. Putusan hakim yang diikuti oleh hakim-hakim selanjutnya terhadap perkara yang serupa inilah yang menjadi yurisprudensi tentang delik zina dalam Pasal 284 KUHP.

Melalui putusan-putusan hakim, secara tidak langsung membentuk yurisprudensi berdasarkan beberapa putusan pengadilan di daerah-daerah yang menjumpai kasus ini. Yurisprudensi tersebut di tiap-tiap daerahnya berbeda, sebab putusanputusan hakim mengacu kepada nilainilai yang berlaku di masyarakat pada saat itu. Nilai-nilai yang hidup dalam masyarakat di tiap daerah tentunya tidak sama sehingga menghasilkan putusan pengadilan yang berbeda-beda. Terhadap hal ini (persetubuhan dengan atas dasar suka sama suka tanpa paksaan terhadap lawan jenis yang juga sama-sama lajangnya) putusan pengadilan menyesuaikan dengan keadaan masyarakat di daerah tersebut.

Berdasarkan latar belakang, penulis berpendapat bahwa Penelitian ini adalah penting dilakukan mengingat landasan bahwa Indonesia adalah Negara Hukum yang berarti segala perbuatan yang dilakukan seseorang memiliki konsekuensi hukum, dan karenanya hukum di Indonesia harus jelas dan menjamin kepastian di dalamnya. Maka dari itulah penulis memiliki minat serta ketertarikan untuk meneliti secara lebih lanjut dalam Penelitian ini.

Rumusan Masalah yang akan dibahas pada penelitian adalah Tentang Bagaimana Rekonstruksi terhadap delik zina berdasarkan pandangan hukum islam sebagai salah satu faktor penunjang dari perkembangan Hukum Pidana Nasional.

\footnotetext{
${ }^{3}$ Adami Chazawi, Tindak Pidana Mengenai Kesopanan, Jakarta, RajaGrafindo Persada, 2005, hlm 57
} 


\section{METODE PENELITIAN}

Penelitian ini menggunakan pendekatan yuridis normatif untuk mengkaji kedudukan yuridis pada hukum pidana dalam salah satu kajian dengan berlandaskan kepada hukum islam terhadap satu norma yakni Pasal 284 KUHP. Sementara penelitian ini penulis menggunakan tiga jenis pendekatan yakni Statute Approach (Pendekatan Peraturan Perundangundangan), Conceptual Approach (Pendekatan Konsep), Comparative Approach (Pendekatan Perbandingan), dan Case Approach (Pendekatan Kasus).

\section{PEMBAHASAN}

\section{Perkembangan Hukum Pidana Tentang Delik Zina Dalam Perkembangan Yuriprudensi Hukum Pidana Nasional}

\subsection{Yurisprudensi Sebagai Bagian dari Penemuan Hukum}

Penemuan hukum adalah suatu metode untuk mendapatkan hukum dalam hal peraturannya sudah ada akan tetapi tidak jelas bagaimana penerapannya pada suatu kasus yang konkret. Penemuan hukum (rechtsvinding) adalah proses pembentukan hukum oleh hakim atau aparat hukum lainnya yang ditugaskan untuk penerapan peraturan hukum umum pada peristiwa hukum konkret. Hakim selalu dihadapkan pada peristiwa konkret, konflik atau kasus yang harus diselesaikan atau

${ }^{4}$ Pasal 5 Undang-Undang Nomor 48 Tahun 2009 Tentang Kekuasaan Kehakiman. dipecahkannya dan untuk itu perlu dicarikan hukumnya. Jadi, dalam menemukan hukumnya untuk peristiwa konkret. Dasarnya ialah kepada Pasal 5 ayat (1) UndangUndang Nomor 48 tahun 2009 Tentang Kekuasaan Kehakiman yang menyatakan bahwa

"Hakim dan hakim konstitusi wajib menggali, mengikuti, dan memahami nilai-nilai hukum dan rasa keadilan yang hidup dalam masyarakat"4

Lalu juga dikaitkan dengan asas Ius Curia Novit, Hakim dianggap tahu hukum, dalam menyelenggarakan peradilan, hakim dilarang menolak perkara dengan alasan tidak ada atau tidak jelas dasar hukumnya. Bilamana dihadapkan dengan kenyataan sebagaimana tersebut, hakim wajib melakukan penemuan hukum demi penyelesaian perkara.

\subsection{Putusan-Putusan}

\section{Pengadilan Mengenai Persetubuhan Sesama} Lajang

Dalam batas tertentu, terdapat beberpa kasus zina yang telah diangkat sebagai yurisprudensi, yaitu kasus zina yang mengakibatkan wanita yang bersangkutan hamil dan laki-laki pasangan zinanya tidak bertanggung jawab dan tidak bersedia mengawini wanita 
tersebut. Kasus-kasus tersebut diantaranya:

1. Putusan Mahkamah Agung No. 93/K/Kr/1996 tertanggal 19 November 1977, dalam kasus zina yang terjadi di Daerah yang merupakan wilayah hukum pengadilan Negeri Aceh. Dalam kasus ini si wanita hamil dan para terdakwa dinyatakan bersalah melakukan tindak pidana adat zina.

2. Putusan Mahkamah Agung No. 195/K/Kr/1979 tertanggal 19 Oktober 1979, terdakwa dinyatakan bersalah melakukan tindak pidana adat bali yaitu Lokika Sanggraha menghamili wanita yang bukan istrinya dan tidak bersedia mengawininya.

3. Putusan Mahkamah Agung No. 845/K/Pid/1983 tertanggal 19 September 1983, terdakwa dinyatakan bersalah melakukan tindak pidana adat di bali yaitu Lokika Sanggraha. $^{5}$

4. Putusan PN Gianyar No. 23/Pid/Sum/1976 jo putusan PT Denpasar No. 14/Ptd/1977 jo putusan MA No. $\quad 195 \mathrm{~K} / \mathrm{Kr} / 1978$. Hubungan kelamin di luar nikah laki-laki dewasa dan perempuan dewasa atas dasar suka sama suka, dimana laki-laki pelaku tidak mau bertanggung jawab ketika si perempuan hamil, menurut (hukum) adat merupakan perbuatan yang tidak patut untuk dilakukan dan harus diberi sanksi, sekalipun KUHP tidak mengaturnya. ${ }^{6}$

5. Putusan PN Klungkung No. 33/Pid.Sumir/1983 jo Putusan MA No. 854K/Pid/1983. Hakim pertama tidak mempertimbangkan keterangan saksi lainnya yang pada hakikatnya memberikan petunjuk tentang kebenaran dakwaan bahwa telah bersetubuh dengan saksi korban. Menurut Yurisprudensi MA, seorang laki-laki yang terbukti tidur bersama dengan seorang perempuan dalam satu kamar dan pada satu tempat tidur, merupakan bukti petunjuk bahwa lakilaki tersebut telah bersetubuh dengan perempuan itu. Berdasarkan keterangan saksi korban dan bukti petunjuk dari para saksi lainnya, maka terbukti bahwa telah bersetubuh dengan saksi korban sebagaimana dimaksud dalam dakwaan subsidair.

${ }^{6}$ H. Pontang Moerad BM, 2005, Pembentukan Hukum Melalui Putusan Pengadilan Dalam Perkara Pidana, Bandung, Alumni, hlm. 274 
Mengenati dakwaan primair, tidak terbukti karena unsur barang tidak terbukti secara sah dan meyakinkan. Intinya, menyatakan terdakwa bersalah terhadap dakwaan subsidair melakukan tindak pidana adat Lokika sanggraha. ${ }^{7}$

6. Putusan PN No. 89/Pid/B/1997/PN.Dps yang menyatakan bahwa terdakwa dinyatakan secara sah dan meyakinkan bersalah melakukan delik pidana adat lokika sanggraha dengan sanksi pidana penjara selama satu bulan.

7. Putusan PN No. 49/Pid.B/2000/PN.Gir menyatakan terdakwa terbukti secara sah dan meyakinkan bersalah melakukan tindak pidana/delik adat lokika sanggraha dengan pidana penjara selama tiga bulan.

Dengan adanya beberapa Putusan Pengadilan Negeri serta Putusan dari Mahkamah Agung tersebut merupakan fakta yang memperkuat upaya merumuskan kriminalisasi perbuatan zina dalam arti luas, meliputi semua bentuk persetubuhan yang dilakukan diluar perkawinan.

\section{Kriminalisasi Delik Zina}

\subsection{Dari Perspektif Kitab Undang-Undang Hukum Pidana}

KUHP Indonesia yang berlaku adalah warisan dari WvS Belanda yang mana didalamnya memuat nilai-nilai yang dianut budaya bangsa Belanda. Dan sebagaimana yang diketahui masyarakat pada umunya, di Belanda hubungan hukum dengan standar moral dapat dikatakan agak renggang, sehingga penetapan tindak pidana kesusilaan tidak didasarkan pada perbuatan yang dilakukan, melainkan didasarkan kepada akibat dari perbuatan yang dilakukan. Perzinaan merupakan delik aduan absolut sebagaimana yang diatur dalam KUHP, hal ini semakin menguatkan bahwa perzinaan yang ada di dalam KUHP betul-betul menitik beratkan atas perbuatan yang mencederai perkawinan. Karena penuntutan baru bisa dilakukan atas pengaduan dari suami atau istri yang tecemar. Pasal ini ditujukan untuk menghindari serta mencegah kemungkinan perbuatan yang akan mencederai perkawinan.

Berkaitan dengan kebijakan kriminalisasi atas delik zina ini, sebetulnya usulan mengenai kriminalisasi atas perbuatan ini telah menjadi program pada perumusan KUHP yang baru yakni

${ }^{7}$ Ibid, Pontang Moerad BM, 2005, hlm 276 
dirumuskan pada pasal 484 ayat (1) huruf e RUU KUHP yang bunyinya adalah sebagai berikut:

(1) Dipidana karena zina, dengan pidana penjara paling lama 5 (lima) tahun:

a. laki laki yang berada dalam ikatan perkawinan melakukan persetubuhan dengan perempuan yang bukan istrinya;

b. perempuan yang berada dalam ikatan perkawinan melakukan persetubuhan dengan laki laki yang bukan suaminya;

c. laki laki yang tidak dalam ikatan perkawinan melakukan persetubuhan dengan perempuan, padahal diketahui bahwa perempuan tersebut berada dalam ikatan perkawinan;

d. perempuan yang tidak dalam ikatan perkawinan melakukan persetubuhan dengan laki laki, padahal diketahui bahwa laki laki tersebut berada dalam ikatan perkawinan; atau

e. laki-laki dan perempuan yang masing-masing tidak terikat dalam perkawinan yang sah melakukan persetubuhan. ${ }^{8}$
8 VIVAnews, diakses melalui website: http://fokus.news.viva.co.id/news/read/399285 -ada--kumpul-kebo--di-rancangan-kuhp, yang dipublikasikan pada Kamis, 21 Maret 2013 | 21:34 WIB

\subsection{Dari Perspektif Hukum Adat}

Agar dapat melengkapi kelemahan yang ada dalam rumusan pasal 284 KUHP sebagaimana yang menjadi topik pembahasan dalam penelitian ini, maka perlu memasukkan unsurunsur hukum adat kedalamnya. Kontribusi hukum adat dapat diabsorbsi atau diserap ke dalam hukum pidana positif Indonesia ${ }^{9}$, khususnya pada pasal perzinaan ini. Dengan memasukkan unsur-unsur hukum adat yang berlaku di Indonesia sebagaimana yang telah dijabarkan oleh penulis pada halaman-halaman sebelumnya, maka kiranya dapat memperluas penafsiran atas pasal 284 KUHP.

Masyarakat Indonesia adalah masyarakat yang religius $^{10}$ sekalipun Indonesia bukanlah Negara Islam seperti Negara Malaysia, Arab Saudi, dan Negaranegara di Timur Tengah lainnya. Karena masyarakatnya yang religius, maka dalam perumusan tindak pidana kesusilaan nilai-nilai agama memiliki pengaruh yang cukup besar di dalamnya. Dengan memperhatikan nilai-nilai agama tersebut maka akan terjadi kriminalisasi perbuatan kesusilaan yang mana menurut agama dikategorikan sebagai perbuatan yang terlarang dan belum ditampung dalam KUHP. ${ }^{11}$

9 Makhrus Munajat, Dekonstruksi Hukum Pidana Islam, Yogyakarta, Logung Pustaka, 2004, hlm 172

${ }^{10}$ Masruchin Rubai, Op.cit, hlm 61

${ }^{11}$ Ibid, hlm 61 


\subsection{Konsep Zina Dalam KUHP}

Dasar Hukumnya ada pada Pasal 284 KUHP. Delik zina diadopsi dari WvS, produk hukum Pemerintah kolonial Belanda pada zaman pendudukan atau penjajahan bangsa Belanda. Dasar pemidanaan perbuatan zina dalam WvS Belanda adalah karena hukum Belanda memandang bahwa perbuatan zina atau Overspeel adalah perbuatan pengkhianatan atas perkawinan. ${ }^{12}$ Karena adanya asas monogami mutlak dalam BW, secara otomatis melarang seseorang melakukan persetubuhan dengan orang lain selain pasangannya, karena zina dianggap merugikan pasangan kawinnya. Dari rumusan delik zina dalam Pasal 284 KUHP, menurut Adami Chazawi dalam bukunya bahwa terdapat 3 unsur esensial dalam unsur-unsur perzinaan, unsur-unsur esensial itu antara lain:

1. melakukan persetubuhan dengan perempuan atau laki-laki bukan suami atau bukan istrinya

2. bagi dirinya berlaku pasal $27 \mathrm{BW}$

3. dan dirinya sedang dalam ikatan perkawinan. ${ }^{13}$

Dalam Pasal 284 KUHP, pada ayat (2) dapat diketahui bahwa Tindak Pidana Perzinaan merupakan delik aduan absolut $^{14}$ yang berarti

12 Andi Hamzah, Asas-Asas Hukum Pidana, Jakarta, Rineka Cipta, 2010, hlm 94

13 Adami Chazawi, Op.cit, hlm 57

${ }^{14}$ Ibid, hlm 61 diperlukannya suatu pengaduan dari suami atau istri yang tercemar. KUHP merumuskan bahwa persetubuhan merupakan delik zina apabila para pelaku atau minimal salah satu pelakunya masih terikat dalam perkawinan dengan orang lain. Persetubuhan di luar perkawinan, antara dua orang yang sama-sama lajang adalah bukan merupakan tindak pidana perzinaan dan tidak dapat dipidana menurut KUHP.

\subsection{Konsep Zina Dalam Hukum Islam}

Zina adalah tindakan melakukan hubungan seksual yang diharamkan oleh dua orang atau lebih yang bukan suami istri, berlaku bagi siapa saja yang berhubungan badan baik bagi yang sedang atau tidak sedang terikat perkawinan. ${ }^{15}$ Berikut merupakan salah satu ayat yang menunjukkan larangan tentang zina:

“...Dan janganlah kamu mendekati zina; sesungguhnya zina itu adalah suatu perbuatan yang keji dan suatu jalan yang buruk..." (QS Al Israa $17: 32)$

Zina merupakan salah satu dosa besar selain Syirik, Durhaka, dan lain-

${ }^{15}$ Asadulloh Al Faruk, Hukum Pidana Dalam Sistem Hukum Islam, Bogor, Penerbit Ghalia Indonesia, 2009, hlm 24-25 
lainnya. ${ }^{16}$ Dalam pelaksanaan hukumannya, dibagi menjadi dua macam yakni Muhsan yaitu bagi pelaku yang masih Terikat Perkawinan dan Ghairu Muhsan yakni bagi pelaku yang berstatus lajang.. Hal ini dibedakan didasari oleh pertimbangan bahwa pernah atau belum pernahnya seseorang melakukan persetubuhan dengan lawan jenis. ${ }^{17}$ Hukumannya berbeda, bagi yang ghairu muhsan hukumannya lebih ringan ketimbang bagi yang muhsan. Dalam Hukum Islam pembuktian zina harus dilakukan dengan adanya kesaksian empat orang saksi yang syarat-syaratnya adalah laki-laki, baligh, berakal, dan adil serta memberikan kesaksian yang sama tentang tempat, waktu, pelaku dan cara melakukannya.

\section{Perbandingan Antara Hukum Pidana Dengan Hukum Islam Terkait Dengan Tindak Pidana Perzinaan Berdasarkan Dalam Pasal 284 Kitab Undang-Undang Hukum Pidana}

\subsection{Konsep Dan Definisi Perbuatan}

Secara garis besar, zina adalah hubungan badan atau seksual yang dilakukan oleh dua orang lawan jenis yang bukan pasangan sahnya (suami/istrinya), bukan dipandang dari sudut status pelakunya yang

${ }^{16}$ M. Nurul Irfan, Gratifikasi \& Kriminalitas Seksual Dalam Hukum Pidana Islam, Jakarta, AMZAH, 2014, hlm 59

17 Prof. Zainudin Ali, Hukum Pidana Islam, Jakarta, Sinar Grafika, 2012, hlm 49

18 Prof. Jur. Andi Hamzah, Delik-Delik Tertentu (Speciale Delicten) Di Dalam sedang terikat perkawinan atau tidak. Hukum Islam memandang bahwa setiap hubungan kelamin atau persetubuhan di luar nikah sebagai zina. ${ }^{18}$ Sebaliknya, hukum pidana tidak memandang semua persetubuhan di luar perkawinan sebagai perbuatan zina melainkan ada syarat-syarat tertentu. Pada umumnya perbuatan yang dianggap sebagai zina dalam hukum pidana hanyalah persetubuhan yang dilakukan oleh orang-orang yang berada dalam status bersuami atau beristri saja Selain dari itu tidak dianggap sebagai zina. ${ }^{19}$

Ditinjau dari Definisinya, dalam hukum islam istilah zina lebih luas cakupannya, tidak terbatas kepada status kedua pelaku yang masih sama-sama lajang, tetap dapat dijerat. Lain halnya dengan KUHP. Berdasarkan konsep zina yang ada dalam Pasal 284, secara eksplisit diterangkan bahwa pelaku zina, baik semua atau paling tidak salah satu pelakunya harus masih sedang terikat dalam ikatan perkawinan yang mana berarti disini bahwa pelaku yang berjenis kelamin lakilaki tersebut harus sudah beristri, dan bagi pelaku yang perempuan maka perempuan tersebut harus

KUHP, Jakarta, Sinar Grafika, 2011, hlm 160. Dalam Bukunya Prof. Jur. Andi Hamzah menyebutkan secara eksplisit bahwa “....semua hubungan kelamin di luar nikah adalah kejahatan menurut hukum islam, yang disebut zina..".

19 Ahmad Wardi Muslich, Hukum Pidana Islam, Jakarta, Sinar Grafika, 2016, hlm 3 
bersuami. Istilah zina pengertiannya lebih sempit, karena ruang lingkupnya berada dalam lingkungan perkawinan sehingga tidak bisa menjerat manakala dilakukan oleh sepasang laki-laki dan perempuan yang masih samasama lajang.

Ditinjau dari Definisinya, maka ditemukan perbedaan, dalam hukum islam istilah zina lebih luas cakupannya, tidak terbatas kepada status kedua pelaku yang masih sama-sama lajang, tetap dapat dijerat. Lain halnya dengan KUHP yang mana istilah zina pengertiannya lebih sempit, karena ruang lingkupnya berada dalam lingkungan perkawinan sehingga tidak bisa menjerat manakala dilakukan oleh sepasang laki-laki dan perempuan yang masih samasama lajang.

Berdasarkan konsep zina dalam KUHP, yang ada dalam Pasal 284, secara eksplisit diterangkan bahwa pelaku zina, baik semua atau paling tidak salah satu pelakunya harus masih sedang terikat dalam ikatan perkawinan yang mana berarti disini bahwa pelaku yang berjenis kelamin laki-laki tersebut harus sudah beristri, dan bagi pelakunya yang perempuan maka perempuan tersebut harus bersuami. Dengan kata lain, jika pada pasangan zina, baik pelaku laki-lakinya maupun bagi pelaku perempuannya bila tidak berlaku Pasal 27 BW baginya (masih terikat perkawinan), maka keduanya tidak dianggap melakukan kejahatan zina, baik sebagai pelaku pembuat (dader) maupun sebagai pelaku zina turut serta melakukan kejahatan zina. ${ }^{20}$ Letak kesamaan menurut perspektif KUHP dan hukum islam adalah pada perbuatan yang dilarang menurut ketentuan hukum pidana juga diharamkan dalam hukum islam. Persetubuhan tersebut dilakukan diluar perkawinan dan bukan dengan pasangan kawinnya, yang mana berarti seorang laki-laki ataupun wanita yang sudah memiliki pasangan kawin melakukan persetubuhan dengan lawan jenisnya yang mana diketahui lawan jenisnya tersebut (pasangan zinanya) adalah bukan pasangan kawinnya.

\subsection{Kualifikasi Pelaku}

Dalam Islam tidak dibedakan status pelaku dalam hubungan pertanggungjawaban pidananya (budak, majikan, yang sudah kawin dengan yang belum kawin). Maksudnya pada poin ini adalah dalam penerapan sanksinya, agama islam tidak memandang status dan kualitas pelaku, baik muhsan maupun ghairu muhsan, budak, majikan, semua yang melakukan persetubuhan diluar hubungan perkawinan adalah pelaku zina. Berbeda halnya dengan KUHP

20 Op.cit, Adami Chazawi, Tindak Pidana Mengenai Kesopanan, hlm 58 
yang menentukan kualifikasi tindak pidananya berdasarkan status dan kualitas pelakunya, sehingga penerapan sanksi untuk para pelakunya dibedakan masingmasing.

\subsection{Rumusan Delik}

Dikaji dari sudut pandang rumusan deliknya, delik perzinaan dalam pasal 284 KUHP baru bisa dilakukannya suatu penuntutan terhadap pelaku setelah adanya pengaduan dari pihak korban yaitu suami atau istri yang tercemar akibat dilakukan perbuatan zina tersebut. Selama suami atau istri yang tercemar tersebut tidak mengadukan perbuatan tersebut, walaupun suami atau istri yang tercemar tersebut mengetahui dan dapat membuktikan bahwa pasangan kawinnya melakukan zina, tidak akan bisa dilakukan penuntutan terhadap pelakunya bila tidak mengadukannya.

Dikaji dari sudut pandang rumusan deliknya, penulis mendapatkan perbedaan diantara keduanya. Dalam ranah hukum pidana, seperti yang sudah diungkapkan penulis sebelumnya di dalam kajian pustaka dan pada halamanhalaman sebelumnya bahwa delik perzinaan dalam pasal 284 KUHP adalah merupakan delik aduan absolut dimana baru bisa dilakukannya suatu penuntutan terhadap pelaku setelah adanya pengaduan dari pihak korban yaitu suami atau istri yang tercemar akibat dilakukan perbuatan zina tersebut. Selama suami atau istri yang tercemar tersebut tidak mengadukan perbuatan tersebut, walaupun suami atau istri yang tercemar tersebut mengetahui dan dapat membuktikan bahwa pasangan kawinnya melakukan zina, tidak akan bisa dilakukan penuntutan terhadap pelakunya bila tidak mengadukannya. Karena merupakan delik aduan absolut, maka orang lain tidak bisa ikut campur dan hak penuntutan hanya ada pada suami atau istri yang tercemar tersebut. Sekalipun orang lain tersebut adalah kerabat suami/istri yang tercemar tersebut dan mengetahui bahwa adanya perbuatan zina, namun tetap orang lain tidak bisa melakukan penuntutan terhadap perzinaan yang dilakukan oleh pelaku dan pasangan zinanya.

Sementara itu dalam hukum islam tidak dikenal istilah delik aduan. Lebih tepatnya ialah Jarimah. Suami atau istri yang bersangkutan tidak harus melaporkan kepada pihak yang berwajib, karena pelaku bisa segera diproses berdasarkan sanksi hukum islam, karena pengaduan bisa dilakukan oleh orang lain meskipun bukan suami atau istri yang melakukan zina. Tetapi, sebagai pihak yang melakukan pengaduan terdapat ketentuan yang harus dipatuhi sebagaimana dengan keterangan "empat orang saksi yang memenuhi kriteria". Dalam hukum 
islam mengadukan seseorang yang telah berbuat zina sangat besar resikonya. Menurut salah satu ayat Al-quran disebutkan bahwa menuduh orang yang berzina, dan bila tidak dapat membuktikan tuduhannya, maka orang yang menuduh tersebut tidak berhak mendapatkan kepercayaan dari masyarakat hingga akhir hayatnya.

“...Orang-orang yang menuduh wanita-wanita yang baik-baik (berbuat zina) dan mereka tidak mendatangkan empat orang saksi, maka deralah mereka (yang menuduh itu) delapan puluh kali dera, dan janganlah kamu terima kesaksian mereka buat selama-lamanya. Dan mereka itulah orang-orang fasik.." (QS. An-Nur 24: 4)

“...Sesungguhnya orangorang yang menuduh wanitawanita yang baik-baik yang tengah lagi beriman (berbuat zina), mereka kena laknat di dunia dan akhirat, dan bagi mereka azab yang besar. Pada hari (ketika) lidah, tangan, dan kaki mereka menjadi saksi atas mereka terhadap apa yang dahulu mereka kerjakan. Di hari itu, Allah akan memberi mereka balasan yang setimpal menurut semestinya, dan tahulah mereka bahwa Allah lah yang benar, lagi yang menjelaskan segala sesuatu

${ }^{21}$ Prof. Zainudin Ali, 2012, Op.cit, hlm 53-54

${ }^{22}$ KUHP, Op.cit, Pasal 284 ayat (1) menurut hakikatnya yang sebenarnya..." (QS. An-Nur 24: $23-24)^{21}$

Jadi, perbedaannya ialah dalam KUHP proses hukum perzinaan baru bisa dilakukan bila ada aduan dari suami/istri yang tercemar, sementara dalam hukum islam tidak harus dari suami/istri, pengaduan bisa dilakukan orang lain bila pengaduan itu memenuhi syarat secara hukum islam.

\subsection{Sanksi Hukum}

Menurut sanksi dalam KUHP, Hukuman pidananya ialah 9 Bulan Penjara $^{22}$ Bagi untuk seorang lakilaki yang sudah beristri atau seorang wanita yang sudah bersuami dan 9 bulan penjara juga bagi pasangan turut sertanya yakni untuk seorang laki-laki atau wanita yang sudah menikah ataupun masih lajang.

Menurut hukum islam, sesuai dengan kategorinya, bagi pelaku zina berstatus Lajang (Ghairu Muhsan) adalah Dera cambuk seratus kali ditambah pengasingan selama setahun dan bagi pelaku zina yang sudah menikah (Muhsan) adalah lebih berat yakni Rajam hingga Meninggal Dunia. ${ }^{23}$

“...Perempuan yang berzina dan laki-laki yang berzina, maka deralah tiap-tiap seorang dari keduanya seratus kali dera, dan

\footnotetext{
${ }^{23}$ Op.cit, Ahmad Wardi Muslich, hlm 29
} 
janganlah belas kasihan kepada keduanya mencegah kamu untuk (menjalankan) agama Allah, jika kamu beriman kepada Allah, dan hari akhirat, dan hendaklah (pelaksanaan) hukuman mereka disaksikan oleh sekumpulan dari orang-orang yang beriman..." (QS AnNuur: 24:2)

“...Ambillah dari diriku, ambilah dari diriku, sesungguhnya Allah telah memberikan jalan keluar bagi mereka (pezina). Jejaka dengan gadis, hukumannya dera seratus kali dan pengasingan selama satu tahun. Sedangkan duda dengan janda, hukumannya dera seratus kali dan rajam."(H.R. Muslim, Abu Dawud, dan Turmudzi)

Karena memiliki definisi yang berbeda, maka pengaturan dan ketentuan sanksi terhadap perbuatannya pun berbeda. Hukum Islam mengatur tentang keduanya, baik untuk zina yang telah kawin (Muhsan) maupun untuk pelaku zina yang masih lajang (Ghairu Muhsan). Dalam hukum pidana tidak diatur dan tidak dikategorikan sebagai tindak pidana, sehingga tidak ada ketentuan sanksi, hukum pidana hanya mengatur bagi sepasang pelaku yang mana salah satunya harus masih terikat dalam perkawinan. Sementara dalam hukum islam, sanksi tetap dapat dijatuhkan tidak memandang status keadaan pelakunya, karena keduanya dalam agama Islam sudah terdapat ketentuannya masing-masing berikut sanksinya berdasarkan kriteria pelakunya. Sanksi tersebut berbeda berdasarkan status keadaan pelaku dimana pelaku yang berstatus telah kawin (Muhsan) mendapatkan hukuman yang lebih berat yakni rajam (walaupun terkait hukuman rajam sendiri pun masih terdapat perdebatan didalamnya, namun pelakunya tetap mendapatkan hukuman yaitu minimal dengan cambukan) yang mana berakibat hilangnya nyawa atau minimal cambuk daripada pelaku yang berstatus lajang (Ghairu Muhsan) yang mana hukumannya adalah berupa cambukan serta pengasingan selama satu tahun. Perbedaan antara keduanya bisa dilihat dari Berat ringannya hukuman yang akan dijatuhkan. Hukum islam memiliki sanksi zina yang lebih berat, karena perbuatan zina dalam hukum islam dipandang sebagai pelanggaran atas ketentuan Allah S.W.T. KUHP dianggap lebih ringan karena sanksinya hanya berupa pidana penjara yang hanya menghilangkan kebebasan seseorang untuk beberapa waktu.

\section{Rekonstruksi Dari Pasal 284 Kitab Undang-Undang Hukum Pidana Tentang Perzinaan Dalam Perspektif Hukum Islam}

Segala usaha yang dilakukan melalui pembentukan undang-undang dan 
tindakan dari badan-badan resmi, yang bertujuan untuk menegakkan normanorma pokok dari masyarakat dikenal sebagai suatu kebijakan kriminal dalam arti yang luas. Sedangkan kebijakan kriminal atau politik kriminal (criminal policy) dalam arti sempit diartikan sebagai usaha dari masyarakat untuk menanggulangi kejahatan. ${ }^{24}$ Terkait dengan Kebijakan kriminalisasi atas suatu perbuatan yang dicanangkan menjadi sebuah delik pidana, harus mempertimbangkan beberapa kriteria sebagai berikut yaitu: ${ }^{25}$

1. Perbuatan yang akan dikriminalisasikan adalah perbuatan yang melanggar nilai-nilai yang hidup dalam masyarakat, disukai atau tidak, patut atau tidaknya perbuatan tersebut (adat istiadat, kesusilaan dan agama);

2. Perbuatan yang akan dikriminalisasikan bersifat anti sosial karena merugikan masyarakat atau menimbulkan kerusakan terhadap masyarakat;

3. Kebijakan kriminalisasi harus memperhatikan kapasitas atau kemampuan daya kerja badan-badan penegak hukum;

4. Kebijakan kriminalisasi harus memperhatikan fungsi

${ }^{24}$ Lidya Suryani Widayati, Jurnal Hukum Vol 3 : Revisi Pasal Perzinaan dalam Rancangan KUHP: Studi Masalah Perzinaan di Kota Padang dan Jakarta, Jakarta, Nusantara, 2009, hlm 314

${ }^{25}$ Ibid, hlm 320 dan tujuan hukum pidana untuk menanggulangi kejahatan.

Dalam merumuskan suatu delik atas suatu perbuatan, hukum pidana tetap harus memperhatikan Asas yang fundamental yaitu asas Legalitas. Kebijakan kriminal sendiri juga memiliki faktor lain yang harus diperhatikan dalam menilai suatu perbuatan untuk dirumuskan menjadi suatu perbuatan, yakni asas Legalitas. Sebagaimana yang diketahui bahwa dengan adanya asas legalitas, ${ }^{26}$ maka suatu perbuatan tidak bisa dikenai sanksi pidana jika tidak diatur dalam KUHP.

Dalam merumuskan kebijakan kriminal sebagai upaya melakukan rekonstruksi, para legislator harus berpedomankan kepada kaidah-kaidah dan nilai-nilai sosial yang ada masyarakat, sebagaimana menurut Bassiouni yang dikutip dari buku karangan Ali Zaidan oleh penulis, bahwa nilai-nilai tersebut meliputi pemeliharaan tertib masyarakat, perlindungan warga dari kejahatan, kerugian, atau bahaya yang tak dapat dibenarkan yang dilakukan oleh orang lain, memasyarakatkan kembali para pelanggar hukum (pelaku tindak pidana), serta memelihara keadilan sosial. ${ }^{27}$ Serta, dalam mewujudkan kebijakan tersebut adanya dua pendekatan yang harus dilakukan

\footnotetext{
${ }^{26}$ KUHP, Op.cit, Pasal 1, bunyi pasal 1 ayat (1) juga bisa diartikan sebagai asas legalitas dalam hukum pidana nasional

27 Ali Zaidan, Menuju Pembaruan Hukum
}

Pidana, Jakarta, Sinar Grafika, 2015, hlm 303 
secara bersama-sama yaitu pendekatan yang berorientasi kepada kebijakan dan kepada nilai. ${ }^{28}$ Kebijakan atau upaya penanggulangan kejahatan pada hakikatnya merupakan bagian dari upaya perlindungan masyarakat (social defence) dan upaya mencapai kesejahteraan masyarakat (social welfare). ${ }^{29}$ Oleh karena itu, dapat dikatakan bahwa tujuan akhir dari kebijakan kriminal ialah perlindungan masyarakat untuk mencapai kesejahteraan masyarakat. ${ }^{30}$

Pada dasarnya hukum memang membentuk kehidupan sosial bermasyarakat, namun pada waktu yang sama pula hukum juga dibentuk oleh kondisi keadaan sosial atau masyarakat pada waktu itu, ${ }^{31}$ dan hal ini mengacu kepada nilai-nilai yang hidup pada masyarakat, termasuk pergeseranpergeseran nilai yang timbul didalamnya. Berkenaan dengan hal tersebut, berdasarkan pendapat menurut Mochtar Kusumaatmadja yang dirangkum oleh penulis, bahwa sesungguhnya hukum sebagai norma sosial tidaklah lepas dari nilai-nilai yang berlaku dalam Masyarakat. ${ }^{32}$ Bila terjadi suatu pergeseran, maka hukum yang merupakan norma sosial tersebut akan berubah. Nilai-nilai yang ada pada masyarakat tersebut adalah salah satu

${ }^{28}$ Prof. Masruchin Rubai, Aneka Pemikiran Hukum Nasional Yang Islami, Malang, UM Press, 2012, hlm 32

29 Syamsul Fatoni, Pembaharuan Sistem Pemidanaan: Perspektif Teoritis dan Pragmatis Untuk Keadilan, Malang, Setara Press, 2016, hlm 16

${ }^{30}$ Barda Nawawi, Bunga Rampai Kebijakan Hukum Pidana, Bandung, Citra Aditya Bakti, 2005, hlm 2 faktor pembentuk hukum, karena salah satu dari sumber hukum materiil adalah yang bersumber dari perasaan hukum masyarakat ${ }^{33}$ yang mana dimaksud disini adalah nilai-nilai yang ada pada masyarakat itu sendiri.

Perbuatan zina sebagaimana yang penulis sebutkan dalam pasal 284 KUHP, pada masa kini terjadi pergeseran di dalamnya dan KUHP harus segera dilakukan suatu revisi di dalamnya. Berkaitan dengan zina yang dilakukan orang-orang yang sama-sama masih berstatus lajang, adalah hal yang bertentangan dengan norma kesusilaan di Indonesia. Walaupun belum ada pengaturannya namun hal ini adalah merupakan pelanggaran norma yang ada di masyarakat yakni norma kesusilaan. Di Negara-negara yang menghormati nilai kesusilaan, biasanya masyarakat akan mencela seorang wanita yang hamil tanpa ada suami yang sah, demikian juga halnya di Indonesia yang mana juga menghormati nilai kesusilaan. Perbuatan zina dengan kategori ini (sama-sama lajang) yang mana bukanlah zina sebagaimana yang ada di dalam pasal 284 KUHP berdampak negatif, karena para

\footnotetext{
${ }^{31}$ Prof. Satjipto Rahardjo, Pendidikan Hukum Sebagai Pendidikan Manusia, Yogyakarta, Genta Publishing, 2009, hlm 191

32 Prof. Abdul Manan, Aspek-Aspek Pengubah Hukum, Jakarta, Kencana, 2013, hlm 22

${ }^{33}$ Lysa Angrayni, Pengantar Ilmu Hukum, Pekanbaru, Suska Press, 2014, hlm 78
} 
pelakunya menjadi tidak menghormati nilai-nilai yang ada pada perkawinan. ${ }^{34}$

Perubahan zaman mengakibatkan pergeseran nilai yang ada masyarakat. Dengan adanya pergeseran nilai tersebut maka secara tidak langsung nilai-nilai yang terkandung di dalam hukum akan bergeser atau juga mengalami perubahan, menyusul dengan perubahan yang terjadi di dalam masyarakat. Pegeseran itu akhirnya menimbulkan keinginan terhadap perubaan hukum yang lama atau hukum yang baru sama sekali, dimana yang jelas karena adanya perkembangan dari masyarakatnya, keadaan menuntut hukum untuk melakukan pembaruan.

\section{Kendala Rekonstruksi}

Beberapa kendala tersebut berdasarkan penelitian normatif yang dilakukan penulis antara lain:

\section{Kemajemukan bangsa ${ }^{35}$} kebudayaan di Indonesia cukup beragam dan berbeda-beda, tiap daerah tidaklah sama. Masingmasing memiliki sosial kultural sendiri-sendiri sehingga tidak mudah untuk mendekatkan satu sama lain. Hal ini berpengaruh terhadap proses rekonstruksi atas tindak pidana perzinaan melalui pendekatan perspektif hukum islam. Meskipun mayoritas WNI adalah beragama islam, namun bukan berarti setiap daerah menggunakan dasar ajaran agama islam untuk mengukur suatu perbuatan dinilai benar atau salah. Bahkan menurut seorang pakar yakni Prof. Andi Hamzah, yang dikutip penulis dalam pernyataannya di media, bahwa masih ada daerah yang menoleransi hal tersebut, yang mana berarti perzinaan dengan status lajang (Ghairu Muhsan) tidak dilarang. ${ }^{36}$

2. Kurangnya pengkajian di bidang hukum islam ${ }^{37}$

Ketertinggalan dalam mengembangkan pusat-pusat pengkajian islam disebabkan berbagai macam hal yakni:

a. Secara historis, pusat pengkajian yang tidak menghargai hukum islam yang lebih dahulu berkembang ternyata tidak memberikan tempat kepada para pengkaji hukum islam.

b. Pengkajian hukum islam terletak diantara pengkajian ilmu agama dan pengkajian ilmu hukum, akibatnya aspek pengkajiannya tidak mendalam.

c. Perkembangan kualitas ketaatan umat islam yang lemah, terutama keyakinan

resmi di

34 Prof. Zainudin Ali, Hukum Islam : Pengantar Ilmu Hukum Islam Di Indonesia, Jakarta, Sinar Grafika, 2015, hlm 112

35 Mardani, Hukum Islam: Kumpulan Peraturan Tentang Hukum Islam di Indonesia, Jakarta, Kencana, 2013, hlm 59 36 TEMPO, Pakar Sulit Memperkarakan Kumpul Kebo, atau diakses melalui website http://nasional.tempo.co/read/news/2013/03/2 3/063468926/pakar-sulit-memperkarakankumpul-kebo yang dipublikasikan pada Sabtu, 23 Maret 2013 | 16:34 WIB, akses dilakukan pada tanggal 17 Desember 2015 pukul 22.30 WIB

${ }^{37}$ Mardani, Op.cit, hlm 60 
akidah dan moral yang sulit

dikendalikan sehingga

menimbulkan penurunan

kualitas moral dalam pelaksanaan hukum

d. Masih dianutnya

kebijaksanaan hukum politik

belanda yang memiliki

kepentingan politik seperti umat islam dilarang tunduk pada hukumnya sendiri, belum sepenuhnya kemandirian Peradilan Agama dalam sengketa Perdata, kecuali hukum keluarga.

e. Banyak masalah yang dihadapi umat Islam, sementara belum ada fatwa hukum yang mampu merangkumnya dalam satu perundang-undangan yang bisa diterima oleh semua elemen masyarakat islam. ${ }^{38}$

\section{PENUTUP}

\section{Kesimpulan \& Saran}

Terdapat kelemahan di dalam rumusan tindak pidana perzinaan sebagaimana yang dirumuskan dalam pasal 284 KUHP. Dengan melalui pendekatan kasus yang dilakukan penulis antara perspektif KUHP dengan hukum Islam yang berlaku di Indonesia, dapat dilihat bahwa sanksi pidana hanya dapat diberlakukan pada persetubuhan yang dilakukan oleh lakilaki/perempuan dengan lawan jenis yang keduanya atau paling tidak salah satunya masih terikat dalam perkawinan. Bila keduanya masih sama-sama tidak sedang terikat perkawinan maka tidak dianggap telah melakukan zina dan tidak dapat dipidana. Namun terdapat beberapa kasus di Indonesia yang diambil penulis yang pernah terjadi kasus persetubuhan yang dilakukan laki-laki/perempuan lajang dengan lawan jenisnya yang sama-sama dewasa dan dilakukan dengan dasar sukarela dan mau sama mau. Semua kasus yang dijadikan referensi oleh penulis adalah kasuskasus yang telah memiliki putusan pengadilan dan telah berkekuatan hukum tetap. Putusan-putusan tersebut dijatuhkan oleh hakim dengan cara menggali nilai-nilai yang hidup dalam masyarakat lalu diikuti oleh hakimhakim lainnya sehingga menjadi yurisprudensi nasional guna menyelesaikan perkara sejenis bilamana terjadi perkara yang serupa. Nilai-nilai yang hidup dalam masyarakat tersebut adalah representasi dari kebudayaan masyarakat Indonesia lebih menitikberatkan kepada nilai moral etika kesusilaan, bahwasannya persetubuhan antara laki-laki dengan perempuan yang bukan istrinya adalah dilarang, hanya diperbolehkan setelah adanya ikatan perkawinan dan hanya diperbolehkan melakukan persetubuhan dengan pasangan kawinnya. Dengan mengingat kepada bahwa hukum Islam merupakan salah satu unsur pembentuk hukum nasional, maka peluang untuk dilakukannya amandemen terhadap rumusan delik

\footnotetext{
${ }^{38} \mathrm{Ibid}, \mathrm{hlm} 60$
} 
zina dalam KUHP kiranya dapat dilakukan.

Saran Bagi Legislator, dalam merumuskan Rancangan UndangUndang KUHP terbaru kiranya lebih memperhatikan unsur-unsur dan nilainilai yang hidup pada masyarakat, khususnya dengan memperhatikan atau bahkan menyerap unsur-unsur Islam di dalamnya serta lebih mempertegas sanksi bila dilakukan perubahan terhadap rumusan delik zina. Kondisi masyarakat yang dinamis memerlukan hukum yang progresif sehingga diperlukannya rumusan peraturan perundang-undangan yang lebih menjamin kepastian hukum dengan jangka waktu selama mungkin sehingga bisa terus berjalan dan dapat bersinergi dengan bertumbuhnya masyarakat.

Bagi masyarakat, hendaknya lebih sadar kepada norma, bukan sekedar kepada hukum atau peraturan tertulis saja, serta lebih mampu menyaring informasi dengan baik dan benar, sebab hukum bersifat kaku dan statis. Masyarakat harus lebih taat kepada nilai-nilai yang hidup pada masyarakat dan lebih mempertimbangkan dampak dan akibatnya bila melakukan perbuatan zina sebagaimana yang dijelaskan penulis dalam penelitian ini. Indonesia adalah Negara dengan adat ketimurannya yang kental, dan Indonesia tidak bisa dipersamakan dengan Negara-negara Eropa lainnya yang mana memang melegalkan perbuatan tersebut, karena di Negara Eropa perbuatan tersebut dianggap sebagai perbuatan yang tidak ada korban (persetubuhan dengan status lajang) dan juga bukan merupakan suatu kejahatan.

\section{DAFTAR PUSTAKA}

Buku

Abdul Manan, Aspek-Aspek Pengubah Hukum, Jakarta, Kencana, 2013

Adami Chazawi, Tindak Pidana Mengenai Kesopanan, Jakarta, RajaGrafindo Persada, 2005

Ali Zaidan, Menuju Pembaruan Hukum Pidana, Jakarta, Sinar Grafika, 2015

Andi Hamzah, Asas-Asas Hukum Pidana, Jakarta, Rineka Cipta, 2010

Barda Nawawi, Bunga Rampai Kebijakan Hukum Pidana, Bandung, Citra Aditya Bakti, 2005

H. Pontang Moerad BM, 2005, Pembentukan Hukum Melalui Putusan Pengadilan Dalam Perkara Pidana, Bandung, Alumni

Lysa Angrayni, 2014, Pengantar Ilmu

Hukum, Pekanbaru, Suska Press

Makhrus Munajat, Dekonstruksi Hukum Pidana Islam, Yogyakarta, Logung Pustaka, 2004

Satjipto Rahardjo, Pendidikan Hukum Sebagai Pendidikan Manusia, Yogyakarta, Genta Publishing, 2009

Syamsul Fatoni, Pembaharuan Sistem Pemidanaan: Perspektif Teoritis dan Pragmatis Untuk Keadilan, Malang, Setara Press, 2016

Zainudin Ali, Hukum Islam : Pengantar Ilmu Hukum Islam

Di Indonesia, Jakarta, Sinar Grafika, 2015 
Jurnal/Artikel Ilmiah

Any Ismayanti, Konsistensi Pasal 284

KUHP Terhadap Undang-

Undang Dasar Negara

Republik Indonesia Tahun

1945, Jurnal Hukum Legality,

Vol.24, No.1, Maret 2016-

Agustus 2016, Sekolah Tinggi

Agama Islam Negeri (STAIN)

Kudus, diakses pada tanggal 28

Februari 2019

Budi Suhariyanto, Problema

Penyerapan Adat Oleh

Pengadilan Dan Pengaruhnya

Bagi Pembaruan Hukum

Pidana Nasional, Jakarta, Pusat

Penelitian dan Pengembangan

Hukum dan Peradilan

Mahkamah Agung, MIMBAR

HUKUM Volume 30, Nomor 3,

Oktober 2018

Frederikus Fios, Keadilan Hukum

Jeremy Bentham Dan

Relevansinya Bagi Praktik

Hukum Kontemporer, Jurnal

Hukum HUMANIORA Vol.3

No.1 April 2012

ICJR (Institute For Criminal Justice

Reform), Naskah Rancangan

Kitab Undang-undang

Hukum Pidana (RKUHP)

Hasil Pembahasan Panitia
Kerja R-KUHP DPR RI (24

februari 2017)

Jimly Asshiddiqie, Penegakan

Hukum, diakses dalam jurnal/makalah hukumnya pada tanggal 22 Oktober 2017 pukul 16.10 WIB, melalui website resmi di halaman berikut: http://www.jimly.com/makalah /namafile/56/Penegakan_Huku m.pdf

Lidya Suryani Widayati, Jurnal Hukum Vol 3 : Revisi Pasal Perzinaan dalam Rancangan KUHP: Studi Masalah Perzinaan di Kota Padang dan Jakarta, Jakarta, Nusantara, 2009

\section{Internet}

VIVAnews, diakses pada tanggal 7 April 2019 melalui website: http://fokus.news.viva.co.id/ne ws/read/399285-ada--kumpulkebo--di-rancangan-kuhp, yang dipublikasikan pada Kamis, 21 Maret 2013 | 21:34 WIB

\section{Peraturan Perundang-Undangan}

Undang-Undang Dasar Negara Republik Indonesia Tahun 1945

Kitab Undang-Undang Hukum Pidana Undang-Undang Nomor 48 Tahun 2009 Tentang Kekuasaan Kehakiman.

Surat Edaran Mahkamah Agung (SEMA) No 8 tahun 1980 Tentang Perzinahan 